\title{
Sposoby zapobiegania destrukcyjnym konfliktom w firmie rodzinnej - studium przypadku
}

\begin{abstract}
Mateusz Kabut*
Cecha charakterystyczna firm rodzinnych jest to, że ściśle tącza one dwa obszary życia ludzkiego - rodzinę oraz sferę zawodowa. To specyficzne potaczenie może być źródtem sity $i$ sukcesu przedsiębiorstwa, ale jednocześnie stanowi przyczynę wielu problemów. Jednym z takich zagrożeń jest wysoki potencjat do możliwych destrukcyjnych konfliktów. Celem tego artykułu jest identyfikacja działań stosowanych w praktyce przez przedsiębiorstwa rodzinne osiagajace sukces rynkowy $w$ celu ograniczenia tego ryzyka. Na podstawie studium przypadku jednej $z$ takich firm autor ustalit następujące możliwe rozwiazania: jasne $i$ konsekwentnie przestrzeganie zasad dotyczacych podziału zysku; dbanie o to, by członkowie rodziny nie zajmowali równorzędnych stanowisk kierowniczych oraz wspieranie członków rodziny przy zakładaniu $i$ prowadzeniu swoich wtasnych firm. Na tej podstawie można wnioskować, że w badanym przypadku decydujaca role odegraty szeroko rozumiane czynniki instytucjonalne.
\end{abstract}

Słowa kluczowe: konflikt, firma rodzinna, problemy firm rodzinnych.

Nadesłany: 19.07.2014 | Zaakceptowany do druku 28.08.2015

\section{Methods of the prevention of conflict in the family business - the case study}

The characteristic attribute of family companies is that they closely connect two areas of human life - family and work. This specific connection can be source of strength and the success of company, but at the same time is the cause of many problems. Example of such threat is high risk of destructive conflict. The purpose of this article was to determine how the risk is limited in practice by family businesses that achieve success. Based on a case study of one such company author established the following possible solutions: clear and consistently adhered rules on the distribution of profit; making sure that members of the family do not occupy equivalent positions of leadership and support for family members in establishing and running their own businesses. On this basis it can be concluded that the broad institutional factors in the examined case played a key role.

Keywords: conflict, family business, family business problems.

Submitted: 19.07.2014 | Accepted: 28.08.2015

JEL: L25, L26, M10, Z13

\footnotetext{
Mgr Mateusz Kabut - Uniwersytet Warszawski, Wydział Zarządzania, Katedra Prawnych Problemów Administracji i Zarządzania.

Adres do korespondencji: Uniwersytet Warszawski, Wydział Zarządzania, Katedra Prawnych Problemów Administracji i Zarządzania, ul. Szturmowa 1/3, 02-678 Warszawa; e-mail: mateusz.kabut@gmail.com.
} 


\section{Wprowadzenie}

Firmy rodzinne do niedawna nie stanowiły przedmiotu szczególnego zainteresowania badaczy. Dopiero na przełomie lat 70. i 80. zaczęło się to zmieniać (PARP, 2009, s. 6). Nie powinno to dziwić, gdy uświadomimy sobie, że wśród najstarszych firm ciągle działających na rynku większość stanowią właśnie przedsiębiorstwa rodzinne (Bocheński, 2014). Ponadto, jak wskazują badania, firmy rodzinne stanowią, w zależności od zastosowanej definicji, od $33 \%$ do $70 \%$ wszystkich przedsiębiorstw w USA i Europie Zachodniej oraz wytwarzają od 20\% do 70\% PKB (PARP, 2009, s. 7). Według badań PARP-u (2009) w Polsce przedsiębiorstwa rodzinne stanowią 36\% wszystkich firm sektora MMSP.

Istotna rola firm rodzinnych w gospodarce to nie jedyny powód, dla którego warto zajmować się tą grupą przedsiębiorstw. Na tle innych firm wyróżniają się one specyficzną relacją łączącą działalność gospodarczą z życiem rodzinnym przedsiębiorców (np. Pieper, Astrachan, Manners, 2013, s. 490). W przypadku firm rodzinnych obie te sfery są zazwyczaj ze sobą nierozerwalnie połączone - przenikają się. Co więcej: potrzeby rodziny i firmy czasami konkurują ze sobą o zasoby przedsiębiorców (przede wszystkim ich czas oraz pieniądze). Ta specyfika firm rodzinnych może być źródłem siły i sukcesu przedsiębiorstwa, ale jednocześnie stanowi przyczynę wielu problemów.

Celem niniejszego artykułu jest prezentacja rozwiązań ograniczających ryzyko najpoważniejszego $\mathrm{z}$ nich - wystąpienia destrukcyjnych konfliktów, czyli takich, których końcowy efekt jest niekorzystny dla przedsiębiorstwa. Firmy rodzinne są rozumiane tutaj jako przedsiębiorstwa kontrolowane i zarządzane przez członków szeroko rozumianej rodziny z wyłączeniem osób fizycznych prowadzących działalność gospodarczą, które nikogo nie zatrudniają. Powyższa wielokryteriowa definicja jest często używana w literaturze (np. PARP, 2009). Podobnie rozumieją firmy rodzinne m.in. Kowalewska i in. (2009, s. 60) czy Astrachan i Kolenko (1994, s. 254).

Opracowanie zostało podzielone na trzy części. W pierwszej z nich dokonany został przegląd literatury przedmiotu, w ramach którego przybliżono specyfikę firm rodzinnych, przyczyny powstawania konfliktów oraz zagrożenia, jakie się z nimi wiążą, wraz z proponowanymi sposobami ich rozwiązywania i unikania. W drugiej części omówiono metodykę i wyniki przeprowadzonego badania, natomiast ostatni punkt zawiera wnioski i podsumowuje całość artykułu.

\section{Przegląd literatury}

\subsection{Specyfika firm rodzinnych}

Obecnie nie ulega wątpliwości, że firmy rodzinne w wielu aspektach różnią się od swoich nierodzinnych odpowiedników. Wynika to między innymi $\mathrm{z}$ nakładania się na siebie roli zarządców, właścicieli oraz członków rodziny (Smyrnios i in., 2002, s. 61). Wpływ tego zjawiska na firmę i rodzine nie jest jednak jednoznaczny, ponieważ w niektórych przypadkach role te mogą się uzupełniać, a w innych mogą być całkowicie niespójne. Warto także zwrócić uwagę, że role w firmach rodzinnych czy zarządzanie majątkiem rodzinnym z samej swej natury nie są tak elastyczne jak w przedsiębiorstwach nierodzinnych (Baumoel, 2012, s. 20). Wynika to z większego zaangażowania emocjonalnego czy sentymentów członków rodziny, a także ograniczonej dobrowolności w kształtowaniu więzów rodzinnych.

Ponadto badania wykazują, że firmy rodzinne cechuje specyficzna kultura organizacyjna. Brice i Richardson (2009) w swoim badaniu wykazali, że przedsiębiorstwa rodzinne charakteryzuje mniejszy dystans władzy, większe zaufanie oraz szeroko rozumiana duchowość. Inni autorzy wskazują również, iż w firmach rodzinnych pracownicy są bardziej zaangażowani oraz cechują się większym poczuciem przynależności (np. Leach, 2011, s. 4).

Także badania Millera i Le Breton-Miller (2005, s. 32) sugerują istnienie pewnej odrębności firm rodzinnych. Zdaniem tych autorów w tej grupie przedsiębiorstw częściej spotykane są następujące cechy:

- ciagłość, czyli konsekwentna realizacja istotnego celu po to, by robić coś wyjątkowo dobrze,

- kontakty, czyli budowanie długotrwałych relacji z partnerami i społecznościami,

- społeczność, czyli budowanie przyjaznej, rodzinnej atmosfery w całej organizacji,

- dowództwo, czyli swoboda przedsiębiorcy $\mathrm{w}$ podejmowaniu strategicznych 
decyzji przy jednoczesnej otwartości na opinie innych.

Miller i Le Breton-Miller (2005, s. 12-13) wyróżniają ponadto wyzwania specyficzne dla rodzinnych przedsiębiorstw. Wśród nich znajdziemy między innymi większe zagrożenie konfliktami, szkodliwy nepotyzm czy niewystarczającą akumulację kapitału.

O problemach charakterystycznych dla firm rodzinnych piszą także praktycy. $\mathrm{Na}$ przykład główny udziałowiec i obecny prezes Grupy Raben również zwraca uwagę na szczególne zagrożenie konfliktami w przedsiębiorstwach rodzinnych (Raben, 2008). Uzasadnieniem tego poglądu są doświadczenia Rabena, którego funkcja w firmie przez wiele lat była równorzędna do tej pełnionej przez jego brata (obaj kontrolowali oddziały Grupy Raben). W jego ocenie poważny problem stanowiło to, że prawa, zarówno jego, jak i jego brata, były równe, co prowadziło do powstania dwóch, niezbyt spójnych, ośrodków władzy. Zdaniem Rabena istotnym wyzwaniem dla firm rodzinnych jest pozorna sukcesja czyli sytuacja, w której pokolenie formalnie oddające władzę korzysta ze swojego autorytetu, by ciagle wpływać na sposób zarzadzania przedsiębiorstwem. Ponadto, wśród problemów charakterystycznych dla firm rodzinnych, Raben wymienia uznaniowość kontroli i planowania.

O szczególnych problemach z sukcesją w polskich przedsiębiorstwach rodzinnych piszą natomiast Glinka i Gudkova (2010). Ich zdaniem to, że $34 \%$ przedsiębiorców nie wie, czy będzie przekazywać spółkę następnemu pokoleniu, a aż $68 \%$ planujących sukcesję nie ma jej planu, jest spowodowane brakiem doświadczenia w tym obszarze. Wynika to z tego, że większość polskich firm rodzinnych zarządzana jest przez pierwsze pokolenie, co można wytłumaczyć stosunkowo krótką historią systemu kapitalistycznego opartego na prywatnej własności w naszym kraju.

Problemem silnych i słabych stron charakterystycznych dla przedsiębiorstw rodzinnych zajął się także Sułkowski (2005), który przebadał czterdzieści firm rodzinnych. Wśród mocnych stron typowych dla firm rodzinnych wymienił m.in. wyjątkowo motywacyjny charakter kultury organizacyjnej, przykładanie dużej wagi do wartości rodzinnych czy ponadprzeciętne zaangażowanie członków rodziny w sprawy firmy. W przedsiębiorstwach rodzinnych często występują jednak problemy związane $\mathrm{z}$ osobą założyciela - autorytarny styl zarządzania, opóźnianie sukcesji oraz silne uzależnienie sytuacji firmy od założyciela, co przejawia się między innymi chaosem i ogromnymi perturbacjami w przypadku śmierci założyciela. Według Sułkowskiego dużym problemem firm rodzinnych jest także wysoki potencjał do konfliktów. Jego zdaniem to właśnie umiejętność wykorzystywania istniejących napięć jako twórczego wkładu w rozwój przedsiębiorstwa może przesądzić o sukcesie firmy (Sułkowski, 2005, s. 228).

$\mathrm{Z}$ powyższego przeglądu literatury wynika jednoznacznie, że firmy rodzinne są wyjątkowe. Jednakże wśród badaczy nie ma zgody co do tego, w jaki sposób ta wyjątkowość przekłada sie na działalność przedsiębiorstw rodzinnych. Wyjątkowo zgodni są za to sami przedsiębiorcy. Jak wynika bowiem z badania PARP-u (2009), przeprowadzonego na próbie 1610 firm rodzinnych sektora MMSP, zaledwie 1\% badanych twierdzi, że rodzinność firmy stanowi przeszkodę. Prawie co trzeci respondent był zdania, że rodzinny charakter firmy czasami przeszkadza, a czasami pomaga; natomiast zdecydowana większość stwierdziła, że jest to atut. Bardzo zbieżne wyniki otrzymano także w badaniu Pentora (2009) przeprowadzonym wśród 337 polskich firm rodzinnych - aż trzy czwarte badanych przedsiębiorców nie dostrzegło żadnych problemów charakterystycznych dla rodzinnych firm. Pozostali badani najczęściej wymieniali natomiast spory rodzinne, negatywnie wpływające na działalność $(5 \%)$, problemy wynikające z różnic pokoleniowych $(6 \%)$, znaczny wpływ niepowodzeń biznesowych na rodzinę $(2 \%)$ oraz brak czasu dla rodziny $(2 \%)$.

\subsection{Destrukcyjne konflikty w firmach rodzinnych - przyczyny}

Powyższy przegląd literatury, a także opinie samych przedsiębiorców wskazują dość jednoznacznie, że jednym z najpoważniejszych zagrożeń, na jakie narażone sa firmy rodzinne, jest konflikt. Warto jednak zauważyć, że konflikt sam w sobie jest naturalnym zjawiskiem, które wcale nie musi być szkodliwe dla organizacji. Według De Dreu, Harincka i Van Vianena (1999) konflikt to „proces rozpoczynający się, gdy jednostka lub grupa dostrzega pomiędzy 
sobą a inną jednostką lub grupą różnice i sprzeczności dotyczące interesów, zasobów, wierzeń, wartości czy praktyk istotnych dla nich" [tłum. własne]. Przyjmując te definicje, należy uznać, że konflikt jest konieczny dla rozwoju organizacji. Różnice w opiniach umożliwiają wypracowanie najlepszych możliwych rozwiązań (Walsh 2004, s. 17). Często jednak różnice zdań wśród członków organizacji potrafią powodować negatywne skutki, obniżać efektywność firmy, a nawet doprowadzić do jej upadku.

Nad przyczynami tego niepożądanego stanu rzeczy zastanawiał się Stańczyk (2012), który na podstawie swoich badań wyróżnił trzy możliwe wytłumaczenia. Pierwszym z nich jest fakt przebywania przez przedsiębiorców rodzinnych w zamkniętej przestrzeni społecznej codziennie, zarówno w domu, jak i w pracy, spotykane są te same osoby. Dodatkowo często firmy rodzinne mieszczą się w domu, w którym mieszka przedsiębiorca. W ten sposób nawet fizyczna przestrzeń jest wspólna dla sfery prywatnej i biznesowej. Ograniczona możliwość rozdzielenia tych dwóch istotnych dla każdego człowieka obszarów sprzyja powstawaniu napięć i konfliktów.

Kolejnym istotnym czynnikiem jest to, co Stańczyk (2012, s. 88) nazywa intensywnościa emocjonalnej interakcji. Firma rodzinna, jako część dziedzictwa rodowego, jest zwykle traktowana jako istotny element funkcjonowania rodziny. $\mathrm{Z}$ tego też względu każda rywalizacja o pozycje w przedsiębiorstwie czy też każda istotna decyzja strategiczna wiąże sie z bardzo silnymi przeżyciami i emocjami. Natomiast tam, gdzie uczucia sa intensywne, łatwiej mogą powstawać konflikty.

Ostatnim elementem wyróżnionym przez Stańczyka jest to, że członkowie rodziny buduja w firmie status quo, przejawiajace sie w typowych dla przedsiebiorstw rodzinnych wzorcach. Swietnym przykładem jest niski poziom formalizmu (zarówno w komunikacji, jak i przy podziale ról), który może być przyczyną konfliktów związanych $\mathrm{z}$ mało klarownym podziałem zadań i odpowiedzialności. Ponadto można oczekiwać, że każda zmiana generacji bedzie rodzić napiecia i spory jako naturalne zagrożenie dla istniejącego stanu równowagi. Co więcej, w przeciwieństwie do nierodzinnych odpowiedników, ustępu- jący menedżerowie zazwyczaj ciągle mają wpływ na firme (chociażby jako autorytet w rodzinie) i mogą aktywnie sprzeciwiać się zmianom proponowanym przez młodsze pokolenie.

W nieco inny sposób przyczyny konfliktów ujęli Rhodes i Lansky (2013, s. 10). Ich zdaniem można wyróżnić cztery podstawowe powody, przez które firmy rodzinne są bardziej narażone na powstanie szkodliwych konfliktów. Pierwszym z nich jest mieszanie się ze sobą relacji rodzinnych i biznesowych, co skutkuje większym poziomem złożoności. Kolejnym wyzwaniem charakterystycznym dla firm rodzinnych jest tendencja członków rodziny do unikania eskalacji konfliktu. W dłuższej perspektywie takie zachowanie może prowadzić do dalszego narastania napięcia między członkami rodziny aż do momentu, w którym spór przybierze postać intensywną i przez to bardzo szkodliwą dla całej organizacji (podobnie: Kliska i Aronoff, 1997). Ponadto autorzy twierdzą również, że członkowie rodziny często zbyt silnie reagują na pojawienie się problemu, co także może prowadzić do ostrego konfliktu. Za ostatni powód konfliktów rodzinnych Rhodes i Lansky uznają wyzwania, jakie powstają na skutek tego, że członkowie rodziny żyją, pracują i spędzają niemal cały swój czas ze soba.

Z kolei Leach (2011, s. 29-39) zwraca szczególna uwage na fakt, że relacje rodzinne i biznesowe często są ze sobą sprzeczne. Ten pierwszy system oparty jest bowiem na emocjach, natomiast działalność gospodarcza jest zorientowana bardziej na zadania $\mathrm{i}$ ich realizację. $\mathrm{Z}$ tego też wzgledu w rodzinie cześciej spotykane jest zachowanie podświadome, oparte na tradycji, co z kolei wiąże się $\mathrm{z}$ niechęcią do zmian. Natomiast w biznesie wręcz przeciwnie - każde działanie powinno być świadomie przeanalizowane, a zmiana jest koniecznościa.

Podobnie uważaja Zou, Chiu, Hsu (2014, s. 37-38). Ich zdaniem tylko początkowo firmy rodzinne korzystają z nałożenia się na siebie dwóch systemów - rodzinnego i biznesowego. Z czasem jednak, gdy firma dojrzewa, staje się to problemem i źródłem konfliktów. Ponadto autorzy sugeruja również, że pewne problemy można wytłumaczyć teoria agencji. Wynika to z faktu, że ze względu na niewielkie szanse na przejęcie władzy w firmie pracownicy spoza rodziny (a nawet część członków rodziny) 
mogą zachowywać się oportunistycznie, co z kolei może prowadzić do konfliktów między zarządzającą częścią rodziny a pozostatymi osobami.

Nieco inaczej do tego zagadnienia podszedł Baumoel (2012, s. 20). Jego zdaniem istotnym czynnikiem wpływającym na tak częste destrukcyjne konflikty w firmach rodzinnych jest wspólna historia członków rodziny. Przez dziesiątki lat wspólnego życia zazwyczaj każda rodzina jest świadkiem jakiś negatywnych zdarzeń, które na co dzień nie są pamiętane. Jednak w miarę narastania wyzwań związanych z biznesem te skrywane przez lata negatywne uczucia moga powrócić i stać się przyczyną ostrego konfliktu. Ponadto Baumoel zauważa, że firmy rodzinne mają zwykle ograniczona możliwość dowolnego kształtowania składu personalnego organizacji. Członkowie rodziny, ze względu na naturę przedsiębiorstwa i jego historię, mają zazwyczaj pierwszeństwo $\mathrm{w}$ rekrutacji, a ponadto bardzo rzadko sa zwalniani wbrew własne woli. W tej sytuacji istnieje duże ryzyko, że poszczególne osoby zarządzające firmą będą charakteryzować się odmiennymi cechami, wartościami czy celami. Na przykład mogą różnić się swoją skłonnością do podejmowania ryzyka. W takich warunkach eskalacja konfliktu będzie się zdarzać zdecydowanie częściej. Dodatkowo Baumoel stwierdza, że w wielu rodzinach, niezależnie od tego, czy prowadzą firmę, istnieją ukryte urazy i pretensje. W normalnych warunkach rodziny te są w stanie unikać konfliktu, jednak w momencie, gdy pojawia się wspólne przedsiębiorstwo, jest to już znacznie trudniejsze zadanie. W takim przypadku firma stanowi swoisty zapalnik, który doprowadza do uwolnienia negatywnych emocji, które wcześniej udawało się skutecznie ukrywać.

$\mathrm{Z}$ nieco innego punktu widzenia geneze konfliktów przedstawiają Pieper, Astrachan i Manners (2013, s. 492-494). Wyróżniają oni trzy rodzaje konfliktów w rodzinach prowadzących biznes i opisują je jako metafory. Pierwszą z nich jest „Firma jako kozioł ofiarny”. Podobnie jak u Baumoela przedsiębiorstwo rodzinne jest tylko katalizatorem konfliktów, których źródło tkwi w relacjach rodzinnych. Pieper, Astrachan i Manners uważaja jednak, że w tej sytuacji członkowie rodziny mogą traktować ten zastępczy konflikt, obejmujący swym zasięgiem głównie relacje biznesowe, jako mniej- sze zło. W ten sposób - świadomie lub nie - odwracają oni swoją uwagę od konfliktu źródłowego, którego skutki mogłyby być katastrofalne. Drugą metaforą użytą przez autorów jest „Opóźnianie dojrzewania”. W tym ujęciu rodzice chcą zachować swoje dzieci blisko siebie i wymusić pożądany rodzaj zachowań. W tym celu, w zamian za bezwarunkowe posłuszeństwo i brak samodzielności, dzieci otrzymują korzyści płynące z firmy. Skutkiem takiego zachowania jest niedostateczne przygotowanie młodszego pokolenia do przejęcia firmy po swoich rodzicach, a także negatywny wplyw na rozwój ich kompetencji rodzicielskich i społecznych. To z kolei sprzyja powstawaniu destrukcyjnych konfliktów. Ostatnią metafora użyta przez Pieper, Astrachan i Manners jest „Stagnacja”. Obrazuje ona sytuację, w której ze względu na przywiązanie do tradycji rodzinnych i różnych sentymentów w firmie powstaje silny opór wobec zmian. Otoczenie organizacji staje się coraz bardziej niespójne z modelem biznesowym przedsiębiorstwa rodzinnego. Taka sytuacja sprzyja konfliktom. Świetnym tego przykładem może być sytuacja opisywana przez Rabena (2008). W swoim artykule wskazuje on, jak dużo napięć wiązało się ze sprzedażą nierentownego oddziału firmy, który przez rodzinę był traktowany jak matecznik przedsiębiorstwa. Został on sprzedany dopiero po wielu latach kosztownego podtrzymywania deficytowego oddziału.

\subsection{Zagrożenia wynikające $z$ konfliktów w firmach rodzinnych}

Istnienie konfliktów i napięć nie zawsze musi mieć negatywny wpływ na firmę. Przedsiębiorstwa rodzinne są jednak w szczególny sposób zagrożone przez to, że pojawiającym się sporom będą towarzyszyć poważne, szkodliwe skutki. Wynika to z tego, że koszty wyjścia członka rodziny z takiej firmy są bardzo wysokie, ponieważ może on utracić swój status, przywileje dostępne w organizacji tylko dla rodziny czy nawet prawo dziedziczenia (Kellermanns, Eddleston, 2004, s. 209). Ponadto - ze względu na nakładanie się na siebie prywatnej i zawodowej sfery życia - zagrożenia, jakie wiążą się z konfliktami, są poważniejsze właśnie w firmach rodzinnych.

Stańczyk (2012, s. 90-91) wśród potencjalnych zagrożeń wywołanych licznymi badź intensywnymi konfliktami wymienia spadek efektywności. Jest to w pełni zgodne 
z intuicją - organizacja, w której spory uniemożliwiają sprawną współpracę między jej uczestnikami, nie będzie w stanie działać sprawnie. Co więcej: takie przedsiębiorstwo jest w większym stopniu narażone na inercję oraz wolniej reaguje na sygnały płynące z rynku. Poza tym skłócona rodzina jest bardziej podatna na kryzysy, a jej jakość życia jest istotnie obniżona.

Powyższe skutki w przedsiębiorstwach rodzinnych mogą zostać wzmocnione poprzez istnienie sprzężenia zwrotnego między firmą a rodziną (Stańczyk, 2012, s. 92). Polega ono na tym, że destrukcyjne konflikty $\mathrm{w}$ przedsiębiorstwie i rodzinie mogą się wzajemnie wzmacniać oraz przenosić $\mathrm{z}$ jednego obszaru do drugiego.

Wielu autorów (np. Pieper, Atrachan, Manners, 2013) zwraca także uwage na wpływ konfliktów związanych z rodzinnym biznesem na samą rodzinę. Intensywne i poważne spory mają bowiem negatywny wpływ na jakość życia członków rodziny (Danes, Huddleston-Casas, Leichtentritt i Metz, 2000, s. 271-272). Zdarza się, że po wielu latach wykańczających walk ze sobą nawzajem członkowie rodziny nie utrzymują ze sobą kontaktu czy nawet otwarcie złorzeczą bliskim (Branch, 1998). Takie tragedie rodzinne, tak drastycznie niszczące relacje między członkami rodziny, są najprawdopodobniej najbardziej trwałymi destrukcyjnymi skutkami poważnych i intensywnych konfliktów w firmach rodzinnych.

Spory w firmach rodzinnych zwiększają także szansę na pojawienie się tzw. efektu Freda. Ten termin, inspirowany przez powieść Mario Puzo pt. Ojciec Chrzestny, został użyty po raz pierwszy przez Kidwella, Kellermannsa i Eddleston (2012, s. 504-505). Opisuje on sytuację, w której członek rodziny jest postrzegany przez pracowników i zarządzających przedsiębiorstwem rodzinnym jako przeszkoda i problem dla organizacji. Taka osoba nie posiada wystarczających kompetencji by pracować w firmie, jednakże ma zapewnione ważne stanowisko, ponieważ jest członkiem rodziny. Szkodliwe działania takiej osoby zwykle są niezamierzone, jednakże sama sytuacja stwarza ryzyko, że „Fredo” zacznie celowo łamać normy i zasady panujące $\mathrm{w}$ firmie czy rodzinie. Badanie przeprowadzone przez autorów wskazują, że konflikty pośrednio wpływają na wzrost prawdopodobieństwa pojawienia się w firmie „efektu Freda” (Kidwell, Kellermanns i Eddleston, 2012, s. 513).

Innym możliwym skutkiem niektórych konfliktów w firmie rodzinnej jest ograniczenie możliwości uczenia sie organizacji. Jak wskazują Kellermans i Eddleston (2004), konflikty związane z zadaniami i procesami zazwyczaj mają pozytywny wpływ na organizację, ponieważ ich skutkiem jest powstanie nowej wiedzy w organizacji. Jest to spowodowane m.in. tym, że tego typu spory nie wiążą się $\mathrm{z}$ reguły $z$ negatywnymi emocjami. Inaczej jest jednak $\mathrm{w}$ przypadku konfliktów relacyjnych między członkami organizacji (a więc takich dotyczących ich osobistych poglądów, wierzeń czy przekonań). Tego rodzaju spory wiążą się z negatywnymi emocjami i sprawiają, że pozytywny wpływ konfliktów zadaniowych i procesowych jest niwelowany (Kellermans i Eddleston, 2004, s. 214-215).

\subsection{Destrukcyjne konflikty w firmach rodzinnych - sposoby zapobiegania i rozwiązywania}

Zgodnie z powszechnie akceptowaną regułą lepiej jest zapobiegać niż leczyć. Dyrektywa ta ma zastosowanie także do konfliktów w firmach rodzinnych. W literaturze przedmiotu zdaje się dominować pogląd, że najlepszym sposobem na unikanie szkodliwych konfliktów w rodzinnych przedsiębiorstwach jest odpowiednie zaprojektowanie norm instytucjonalnych opisujących obszary, w których biznes i rodzina nakładają się na siebie. Neufeld (2004, s. 16) radzi na przykład, aby sporządzać porozumienia pomiędzy członkami rodziny (obejmujące także kluczowych pracowników i kadrę menedżerską), które zawierałyby procedury rozwiązywania konfliktów. Keyt i McCann (2013, s. 13-16) sugerują natomiast, by członkowie rodziny na możliwie wczesnym etapie ustalili wspólny cel, uzgodnili razem wartości, misję oraz wizję, a także pamiętali o tym, by na firmę i rodzinę patrzeć holistycznie. Także Kreitler (1998) twierdzi, że należy opracować odpowiednie reguły, gdy tylko $\mathrm{w}$ firmie pojawia pierwsza osoba $\mathrm{z}$ rodziny założyciela. Ponadto należy zdefiniować role, jakie będą odgrywać członkowie rodziny w firmie, sposób, w jaki będą oceniani, a także konsekwencje, jakie grożą im za niewłaściwe zachowanie. Dodatkowo Kreitler radzi, aby każda firma rodzinna znalazła i utrzymała kluczowych pracowni- 
ków niebędących częścią rodziny. Kolejną istotną kwestią jest także opracowanie planu sukcesji, obejmującego też przypadki nagłych zdarzeń.

Zwolennikiem narzucenia określonych instytucjonalnych ram na firmę rodzinną jest również Raben (2008). Jego zdaniem istotne jest wprowadzenie zasady, że tylko dominujący udziałowiec uczestniczy w bieżącym zarządzaniu firmą. Ponadto członkowie rodziny nie powinni pełnić w organizacji równorzędnych funkcji operacyjnych. Dzięki temu ograniczone zostaje ryzyko pojawienia się dwuwładzy, która często bywa źródłem konfliktu. Raben sugeruje także centralizację własności tak, aby istniała możliwość podejmowania najważniejszych decyzji przez jedną osobę. Raben uważa też, że pozytywne efekty może przynieść wprowadzenie planu sukcesji oraz sformalizowanych mechanizmów planowania i kontroli.

Jeżeli jednak w firmie rodzinnej już pojawił się destrukcyjny konflikt, to opanowanie sytuacji jest zwykle trudniejsze. Baumoel (2012, s. 21) wyróżnia trzy możliwe reakcje na zaistnienie niebezpiecznego sporu w przedsiębiorstwie rodzinnym - unikanie, użycie siły lub rozwój. Pierwsze dwa rozwiązania są zazwyczaj skuteczne tylko w krótkim okresie. Z tego też względu znacznie bardziej pożądaną reakcją jest rozwój, który może być zarówno osobisty, jak i organizacyjny. W pierwszym przypadku przedstawiciele rodziny, ucząc się metod rozwiązywania sporów czy zasad rządzących biznesem, sami są w stanie dojść do porozumienia. W drugim przypadku w organizacji powstają nowe procedury i normy, które ograniczają liczbę i intensywność powstających konfliktów.

\section{Studium przypadku}

\subsection{Metodyka badań}

Celem tego badania jest identyfikacja mechanizmów, które pomagają firmom rodzinnym ograniczyć ryzyko powstawania i eskalacji szkodliwych konfliktów. Na podstawie przedstawionej literatury przedmiotu można przypuszczać, że kluczowe znaczenie będzie miał sposób ukształtowania ładu rodzinnego i korporacyjnego. $\mathrm{Z}$ tego też względu zostanie podjęta próba odpowiedzi na pytanie, jakie normy i zasady, uzgodnione w ramach przedsiębiorstwa rodzinnego, ograniczają zagroże- nie destrukcyjnymi konfliktami. W tym celu przeprowadzono badanie metodą studium przypadku wybranej firmy rodzinnej.

Badane przedsiębiorstwo nie zostało wybrane przypadkowo. Podstawowym kryteriami wyboru były: okres istnienia firmy; jej ścieżka rozwoju; sytuacja ekonomiczna oraz wielkość rodziny zarządzającej przedsiębiorstwem. Kierując się tymi wytycznymi, wybrano firmę rodzinną założoną w 1989 roku przez dwóch braci. Pierwszy z nich posiadał równocześnie dobrze prosperującą firmę w Niemczech, w związku z czym zarządzaniem operacyjnym zajmował się od samego początku drugi z braci. Początkowo firma miała produkować kostkę brukową, jednak ze względu na brak popytu na tego typu produkty zdecydowano się na działalność transportową. Z każdym rokiem działalności przedsiębiorstwo zwiększało swoje przychody, liczbę posiadanych samochodów oraz wielkość zatrudnienia. Obecnie firma zatrudnia ok. 150 osób, a przychody rosną $w$ takim tempie, że nieprzerwanie od trzech lat otrzymuje ona tytuł Gazela Biznesu. Wyróżnienie to nadawane jest przez Puls Biznesu tym przedsiębiorstwom, które osiągają dynamikę wzrostu przychodów na poziomie przekraczającym 10\% rocznie. Ponadto badana firma w zeszłym roku skutecznie rozszerzyła swoją działalność o usługi magazynowe. $\mathrm{Z}$ przeprowadzonego przez autora badania ankietowego wynika ponadto, że pracownicy firmy wykazują się ponadprzeciętnym zaangażowaniem w swoją pracę (w porównaniu do wyników badań za pomocą tego samego kwestionariusza przeprowadzonych na próbie 142 Polaków zatrudnionych w różnych firmach - Kulikowski i Madej, 2014). Wszystkie te czynniki wskazują, że badane przedsiębiorstwo jest przykładem zdrowej organizacji, dobrze radzącej sobie na konkurencyjnym rynku. To z kolei sugeruje, że w badanej firmie nie występują destrukcyjne konflikty. Potwierdzają to także obserwacje i wywiady przeprowadzone w ramach niniejszego badania.

Kolejnym interesującym aspektem badanej firmy jest wielkość rodziny właścicieli. Dwaj bracia założyciele mają jeszcze jednego brata. Ponadto obecny prezes ma czwórkę dzieci (trzech synów oraz córka). Każde z nich założyło już swoje rodziny. $\mathrm{W}$ trakcie badania $\mathrm{w}$ badanym przedsiębiorstwie zatrudniony na stanowisku prezesa był jeden z założycieli. Stanowisko 
wiceprezesa zajmował jego syn. Ponadto na szeregowych stanowiskach pracowało dwóch pozostałych synów prezesa. Natomiast w badanej firmie nie była zatrudniona córka. Dodatkowo - także na szeregowych stanowiskach - zatrudnionych było pięciu członków rodziny. Z kolei kierownikami czterech działów firmy były osoby spoza rodziny. Natomiast właścicielami spółki w chwili badania byli prezes $(30 \%$ udziałów) oraz jego czwórka dzieci (po 17,5\% udziałów).

Badanie prezentowanej firmy obejmowało: pogłębiony wywiad $\mathrm{z}$ prezesem, wiceprezesem oraz główną księgową (kierowniczką działu administracyjnego); wielogodzinne obserwacje; ankietę wśród pracowników; a także analizę dokumentów firmy (w tym kroniki przedsiębiorstwa). W trakcie wywiadów oraz obserwacji szczególną uwagę zwrócono na normy i zasady mogące mieć wpływ na pojawianie się szkodliwych dla fïmy konfliktów. Badanie trwało blisko pół roku; w tym czasie firme odwiedzono kilkanaście razy.

Wybrana metoda badawcza pozwala na dobre zidentyfikowanie rozwiązań stosowanych w badanej firmie. Niestety, jak każde badanie jakościowe, ma ona pewne ograniczenia. To, że w badanej organizacj pewne rozwiązania okazuja się skuteczne, nie musi oznaczać, że są to rozwiązania uniwersalne. $\mathrm{Z}$ tego też względu - korzystając z wniosków z tego badania - należałoby przeprowadzić badanie ilościowe większej liczby przedsiębiorstw rodzinnych radzących sobie z destrukcyjnymi konfliktami.

\subsection{Wnioski z badania}

Podczas wielu godzin obserwacji firmy nie zaobserwowano destrukcyjnych konfliktów, pomimo rozmiarów zarówno rodziny, jak i samej firmy. Po dokonaniu analizy materiału badawczego wyróżniono następujące możliwe przyczyny tej sytuacji:

\section{Ustalone i konsekwentnie przestrzegane zasady dotyczące akumulacji kapitału}

W badanej spółce od samego początku jej istnienia panuje zasada, że cały zysk przedsiębiorstwa jest reinwestowany. W ciagu całej 25-letniej historii nigdy nie została wypłacona dywidenda, a kapitały własne firmy zostały uszczuplone tylko raz - w momencie wyjścia ze spółki jednego z współzałożycieli. Pracujący członkowie rodziny otrzymują oczywiście świadczenia ze strony przedsiębiorstwa, jednak są to głównie stałe pensje. Dzięki temu unika się podejmowania decyzji o podziale zysku, która ze względu na samą swą naturę budzi ogromne emocje i może przerodzić sie w poważny konflikt. Ponadto firma, dzięki jasnym regułom preferujacym reinwestowanie zysków, może budować i utrzymywać przewagę konkurencyjną. W przypadku badanego przedsiębiorstwa przejawia się to zarówno w nowoczesnym taborze, jak i w rozpoczęciu działalności magazynowej (dzieki czemu firma może oferować swoim klientom bardziej kompleksowe usługi). Świadczy o tym wypowiedź wiceprezesa: maja średnio 2,5 roku, podczas gdy większość ciągników jeżdżących po polskich drogach ma powyżej 10 lat. Ale żeby było to możliwe, to musimy ciagle inwestować. Wszyscy to rozumiemy i zgadzamy się, by przeznaczać na to cały zysk".

\section{Z kolei zdaniem prezesa:}

"Chcemy dalej być, chcemy się rozwijać, (...) Żeby się rozwijać to trzeba inwestować i każdy to rozumie".

Warto zauważyć, że z góry ustalone i akceptowane przez wszystkich reguły dotyczące tak ważnej kwestii, jaką jest podział zysku, są konkretyzacją postulatu znanego z literatury aby rodzina ustaliła wewnętrzne, akceptowane przez wszystkich zasady, tak aby w przyszłości nie rodziły one konfliktów (np. Keyt i McCann, 2013 oraz Kreitler, 1998).

W omawianej firmie rodzinnej od samego początku działalności unikano sytuacji, w której członkowie rodziny zajmują równoprawne stanowiska kierownicze. Już w pierwszych latach działalności - mimo że było dwóch właścicieli - na bieżąco firma kierował tylko jeden z braci. Najważniejsze decyzje były oczywiście podejmowane wspólnie, co jednak nie wiązało się z szkodliwymi konfliktami. Potwierdzają to słowa prezesa:

„Brat prowadził swoja firmę w Niemczech, która dobrze prosperowała.

Przez to większość czasu spędzał za granica, a tą firmę prowadziłem przede wszystkim ja".

W ostatnich latach, gdy jeden ze wspó1założycieli wycofał się ze spółki, część udziałów została podzielona między dzieci drugiego udziałowca. Nie zmieniło się jednak to, że bieżące zarządzanie firmą i naj- 
ważniejsza pozycja w całej firmie są przypisane do jednej osoby. Co więcej, tylko jedna osoba $\mathrm{z}$ rodziny (poza prezesem) pełni funkcje kierownicze w firmie (wiceprezes, będący synem prezesa). Wszyscy pozostali pracują na szeregowych stanowiskach, dzięki czemu ryzyko powstania dwóch lub więcej zwalczających się ośrodków władzy jest ograniczone. Z przeprowadzonych obserwacji wynika ponadto, że synowie oraz szwagier prezesa sa stosunkowo często proszeni o opinię, jednak nigdy nie dzieje się to bez wiedzy lub wbrew stanowisku kierownika działu, w którym są zatrudnieni. Nie zmienia to jednak faktu, że od członków rodziny oczekuje się tego samego, co od zwykłych pracowników. Konsekwencja przestrzegania tej zasady jest także duża otwartość na kadrę menedżerską z zewnątrz. W okresie przeprowadzania badania zatrudniony został nowy kierownik magazynu. Co ciekawe, nawet przez chwilę nie rozważano kandydatury jednego z członków rodziny, a zatrudniona osoba cechuje się wysokimi kompetencjami i bogatym doświadczeniem $\mathrm{z}$ innych firm. Potwierdzają to słowa wiceprezesa:

„Od początku szukaliśmy kogoś na zewnątrz. Kogoś kto miałby odpowiednie kompetencje i doświadczenie. Szczególnie, że magazyn to dla nas coś nowego".

Należy podkreślić, że zarówno ograniczenie liczby osób z rodziny zajmujących kierownicze stanowiska, jak i starania o pozyskanie i utrzymanie kluczowych pracowników z zewnątrz jest działaniem zgodnym z sugestiami badaczy tego zagadnienia (np. Kreitler, 1998; Raben, 2008).

\section{Stworzenie grupy firm członków rodziny}

„Ja z bratem miałem tą spółkę. Dzieci też rosły, każdy tam ożenił się, wydzielił.

Mówili: Ty masz z bratem firmę i to rośnie, my też chcemy".

W badanej firmie problem ten został rozwiązany poprzez pomoc w założeniu przez członków rodziny (brata oraz dwójke dzieci prezesa) działalności gospodarczych. Dzięki poręczeniom „spółki matki” osoby te mogły kupić ciągniki i naczepy. Co więcej, nowo utworzone przedsiębiorstwa zostały podwykonawcami badanej firmy. Dzięki temu członkowie rodziny uzyskali niezależność finansową oraz autonomię w swoich przedsiębiorstwach. W tej sytuacji łatwiej jest im pogodzić się z tym, że nie mają większego wpływu na zarządzanie „spółką matką”. Również młodsi synowie, gdy dorośli, chcieli niezależności:

„Młodsi synowie też chcieli. Brat był niepocieszony, ale mówie mu: Marcinku ja mam dzieci, ty masz połowę, ja mam połowę, jak to urośnie to co oni będą mieli? Będą tylko pracownikami?"

Ostatecznie także oni otrzymali jakąś formę niezależności. Jednakże w tym przypadku zastosowano inny mechanizm dzieci, wraz z ojcem, założyły spółkę kapitałowa, która także została podwykonawca badanego przedsiębiorstwa. W tym przypadku synowie zyskali co prawda mniejszą niezależność (zostali członkami zarządu nowo powstałego podmiotu), ale za to zyskali ograniczoną odpowiedzialność. Ponadto utworzona spółka $\mathrm{w}$ razie utraty licencji przez „spółkę matkę” w bardzo łatwy sposób może przejąć jej działalność. Potwierdzają to słowa głównej księgowej:

„Obecnie nie jest trudno stracić licencję [na transport drogowy rzeczy]. Przyczyny utraty licencji mogą być niezależne od kierownictwa spółki. Gdyby taka sytuacja nas spotkała, nie bedzie to dla nas koniec świata, bo zamówienia może przejąć druga spółka".

Warto zauważyć, że tego typu rozwiazanie nie znalazło się wśród sugerowanych w literaturze sposobów zapobiegania konfliktom w firmach rodzinnych. Jednakże wydaje się, że taki podział na główną spółke i ściśle z nią współpracujące firmy należące do członków rodzin może ułatwiać (lub wręcz wymuszać) wspólne ustalenie zasad i reguł już na początku współpracy biznesowej w ramach rodziny (np. Keyt i McCann, 2013; Kreitler, 1998).

\section{Stabilna kondycja finansowa przedsiębiorstwa i ciągły rozwój}

Zdaniem prezesa badanej spółki kluczowe znaczenie dla utrzymania dobrej atmosfery w firmie ma ciągły rozwój przedsiębiorstwa oraz dbanie o jego dobrą kondycję finansową. Świadczyć o tym mogą następujące słowa:

„Przede wszystkim właściwa atmosfera, a ta atmosfera bardzo mocno jest uzależniona od kondycji finansowej. To wszystko rzeczy tak mocno powiązane, że jeśli to wszystko funkcjonuje, to to ma rację bytu".

Trudno nie zgodzić się z tym stwierdzeniem, szczególnie w sytuacji, w której wokół badanego przedsiębiorstwa funk- 
cjonuje cały ekosystem firm członków rodziny, który jest również w dużej mierze uzależniony od sytuacji finansowej „spółki matki”. Należy jednak zauważyć, że z tego stwierdzenia wynikają poważne konsekwencje. Jedną z nich jest unikanie nadmiernego ryzyka. Świadczą o tym słowa prezesa:

„Myśmy działali bardzo ostrożnie (...) Nie szło się jak niektórzy - 20 samochodów, niektórzy 50 samochodów, szybko. U nas tego nie było, myśmy bardzo ostrożne ruchy wykonywali".

Kolejną zasadą, która pozwala zachować stabilną kondycję finansową, wydaje się także przekładanie potrzeb firmy nad potrzeby rodziny - jeśli jest to konieczne. Potwierdzają to następujące słowa prezesa:

„Takżeśmy pomaleńku badali ten rynek, wchodzili w ten świat takiego, można powiedzieć, nawet biznesu. Bo nawet człowiek żył skromnie, zresztą tak był wychowywany".

Wydaje się, że takie skupienie na rozwoju firmy w długim terminie oraz świadoma rezygnacja z nadmiernego zaspokajania potrzeb rodziny kosztem firmy również stanowią rozwiązanie zgodne z propozycjami i sugestiami wysuwanymi w literaturze przedmiotu. Warto nadmienić, że wśród podstawowych przyczyn negatywnych konfliktów w rodzinie badacze wymieniaja konkurencję o zasoby pomiędzy rodziną a firmą (np. Pieper, Astrachan i Manners, 2013). W badanej firmie problem ten został rozwiązany, poprzez nadanie priorytetu potrzebom firmy.

\section{Podsumowanie}

Przez ostatnie 25 lat w Polsce obserwuje się dynamiczny rozwój przedsiębiorczości, także tej rodzinnej. Wiąże się to ze wzrostem znaczenia firm rodzinnych dla rodzimej gospodarki. Wiele tych podmiotów jest w stanie świetnie odnaleźć się na konkurencyjnym rynku, często także globalnym. Niestety, nie brakuje również takich przedsiębiorstw rodzinnych, które nie sa w stanie poradzić sobie z problemami - zarówno tymi charakterystycznymi dla całego sektora MMSP, jak i tymi cechujących głównie firmy rodzinne. $\mathrm{Z}$ tego też względu bardzo ważne jest rozpowszechnianie dobrych praktyk, pochodzących od najlepszych rodzinnych przedsiębiorców w kraju.

W tym artykule zaprezentowano możliwe rozwiązanie dla jednego z najpoważ- niejszych zagrożeń przed którymi stoją firmy rodzinne - destrukcyjnych konfliktów. Na przykładzie firmy, która od 25 lat ciągle się rozwija, ustalono, że pomocne może być wdrożenie nastepujacych kroków: a) ustalenie i konsekwentne przestrzeganie zasad dotyczących akumulacji kapitału,

b) unikanie sytuacji, w której członkowie rodziny będą pełnić równorzędne funkcje kierownicze oraz otwarcie na kadrę menedżerską spoza rodziny,

c) stworzenie wokół głównej spółki grupy firm należących do członków rodziny, którzy nie zarządzają bezpośrednio „spółką matką",

d) dbanie o stabilną kondycję finansową przedsiębiorstwa (poprzez unikanie nadmiernego ryzyka oraz przekładanie rozwoju firmy nad potrzeby rodziny)

Warto zauważyć, że wszystkie wskazane rozwiązania są tak naprawdę zbiorem reguł, norm i zasad, które sa przestrzegane $\mathrm{w}$ badanej rodzinie. Jest to w pełni zgodne z wnioskami z krajowej i zagranicznej literatury przedmiotu. W kolejnym etapie należałoby przebadać więsszą liczbe firm rodzinnych pod kątem specyficznych zasad i norm, dzięki którym udaje im się niwelować ryzyko powstawania i eskalacji destrukcyjnych konfliktów.

\section{Bibliografia}

Astrachan, J. i Kolenko, T. (1994). A Neglected Factor Explaining Family Business Success: Human Resource Practices. Family Business Review, 7(3), 251-262.

Baumoel, D. (2012). Getting a grip on conflict. Family Business Magazine, 23(1), 20-21.

Bocheński, A. (2014). Strategia trwania przez pokolenia. Pozyskano z: http://www.sukcesja.org/index php/aktualnosci/134-strategia-trwania-przez-pokolenia (12.07.2014).

Branch, S. (1998). Mom always liked you best: Conflicts are a sure bet in any family firm. The trick is to confront problems before too much damage is done. Your Company, 8(3), 26-34.

Brice, W. i Richardson, J. (2009). Culture in family business: a two-country empirical investigation. European Business Review, 21(3), 246-262.

Danes, S., Huddleston-Casas, C., Leichtentritt, R. i Metz, M. (2000). Effects of conflict styles and conflict severity on quality of life of men and women in family businesses. Journal of Family and Economic Issues, 21(3), 259-286.

De Dreu, C., Harinck, F. i Van Vianen, A. (1999). Conflict and performance in groups and organiza- 
tions. W: C. Cooper i I. Robertson (red.). International Review of Industrial and Organizational Psychology (t. 14, s. 369-414). Chichester: Wiley.

Glinka, B. i Gudkova, S. (2010). Wybrane uwarunkowania rozwoju przedsiębiorczości rodzinnej w Polsce. Problemy Zarzadzania, 8(4): 42-55.

Kellermanns, F. i Eddleston, K.A. (2004). Feuding Families: When Conflict Does a Family Firm Good. Entrepreneurship: Theory and Practice, 28(3): 209-229.

Keyt, A. i McCann, G. (2013). Managing the family/business overlap. Family Business, 24(4): 12-16.

Kidwell, R., Kellermanns, F. i Eddleston, K. (2012) Harmony, Justice, Confusion, and Conflict in Family Firms: Implications for Ethical Climate and the "Fredo Effect". Journal of Business Ethics, 106(4): 503-517, http://dx.doi.org/10.1007/s10551-0111014-7

Kliska, B. i Aronoff, C. (1997). The price of 'peace at any price'. (Managing conflict in a family business). Nation's Business, 85, 46-48.

Kowalewska, A., Szut, J., Lewandowska, B., Kwiatkowska, M., Sułkowski, Ł. i Marjański, A. (2009). Badanie firm rodzinnych - raport końcowy. Warszawa: PARP.

Kreitler, B. (1998) Planning Can Pre-empt Familyrelated Business Conflicts. Pozyskano z: http://www. cbia.com/cbianews/sm_business_tips/199803sbplan ningcanpreemptfamilyrelatedbusinessconflicts.htm (31.08.2014).

Kulikowski, K. i Madej, M. (2014). Zaangażowanie $\mathrm{w}$ prace - problemy z pomiarem. Problemy Zarzadzania, 12(1), 99-112.

Leach, P. (2011). Family Businesses Family Businesses: The Essentials. London: Profile.

Miller, D. i Le Breton-Miller, I. (2005). Managing for the Long Run: Lessons in Competitive Advantage from Great Family Businesses. Harvard Business Press Books.

Neufeld, R. (2004). When family members don't get along. Business Journal Serving Fresno \& the Central San Joaquin Valley, 323261, 16.
PARP (2009). Firmy rodzinne w polskiej gospodarce - szanse $i$ wyzwania. Warszawa: PARP.

Pentor (2009). Badanie firm rodzinnych $w$ Polsce. Pozyskano z: www.firmyrodzinne.pl/download/ pentor/Pentor_Badanie_Firm_Rodzinnych.pdf (12.07.2014)

Pieper, T., Astrachan, J. i Manners, G. (2013). Conflict in Family Business: Common Metaphors and Suggestions for Intervention. Family Relation, 62(3), 490-500.

Raben, E. (2008). Jak pokonaliśmy bariery wzrostu tkwiące w rodzinie właścicieli. HBR Polska, 64, 48-59.

Rhodes, K. i Lansky, D. (2013). Managing Conflict in the Family Business: Understanding Challenges at the Intersection of Family and Business. New York: Palgrave Macmillan, http://dx.doi. org/10.1057/9781137321305

Smyrnios, K., Romano, C., Tanewski, G., Karofsky, P., Millen, R. i Yilmaz, M. (2002). Work-to-family conflict A comparison of American and Australian family and non-family business owners. W: D. Fletcher (red.), Understanding the Small Family Business (s. 61-74). London: Routledge.

Stańczyk, K. (2012). Konflikt i jego specyfika w firmie rodzinnej. W: M. Zawadka (red.), Firma $w$ rodzinie czy rodzina $w$ firmie - metodologia wsparcia firm rodzinnych. Warszawa: PARP.

Sułkowski, Ł. (2005). Przedsiębiorczość w firmach rodzinnych w Polsce - wnioski z badań. W: D. Kopycińska (red.), Konkurencyjność rynku pracy $i$ jego podmiotów (s. 221-228). Szczecin: Wydawnictwo Katedry Mikroekonomii Uniwersytetu Szczecińskiego.

Walsh, T. (2004). Managing family-business conflicts requires tact. The Central New York Business, 18(30), 17.

Zou, W., Chiu, Y. i Hsu, C. (2014). Performance Appraisals Between Family Businesses And NonFamily Businesses. The International Journal of Organizational Innovation, 7(1), 36-45. 